\title{
Renewable Energy in Algeria and Energy Management Systems
}

\author{
Abdelkader Harrouz**, Asma Temmam**, Meriem Abbes** \\ *Department of Hydrocarbon and Renewable Energy, Faculty of Science and Technology, Laboratory of Energy Environment \\ and Information System, Ahmed Draïa University, (01000) BP 252, Adrar, Algeria \\ **Department of Material Science, Faculty of Science and Technology, Ahmed Draïa University, Adrar, Algeria \\ Harrouz@univ-adrar.dz,Temmamikram@gmail.com,Prettymeriem1991@gmail.com
}

$\$$ Corresponding Author: Abdelkader Harrouz, Ahmed Draïa University, Adrar, Algeria, Tel: +33 555251735 ,

Fax : +33 493694 56, harrouz@univ-adrar.dz

Received: 29.01.2018 Accepted: 10.03.2018

\begin{abstract}
Algeria's electricity generation has been recently approached 8,000 MW, as energy consumption continues to grow by $5 \%$ every year. On the other hand, despite the favourable geographical situation of Algeria, but, the development of renewable powers in the country occupy only a small part of the national electricity mix $(0,8 \%)$ and their production is shared between the hydraulic sector which generated this year $(389 \mathrm{GWh})$. Or $0,7 \%$ of the total, and solar photovoltaic (11Gwh) and thermodynamic $(58 \mathrm{GWh})$, which represent $0.1 \%$ of the balance sheet. This article also explains the most used renewable energies for Algeria and shows the efficient applications related to solar, wind, geothermal and biomass energy. At the end an example that includes manoeuvring and managing energy sources on opportunities related to the development of renewable energies.
\end{abstract}

Keywords Renewable power, Solar, Wind, Management, Electricity, Micro grid

\section{Introduction}

Algeria is one of the main players in the world energy markets. It is among the payroll producers and exporters of natural gas and oil because of these stocks in classic energy. It have a very important place in the markets of Natural and liquefied gas, it is the second largest exporter of natural gas in Europe and Africa among the top three oil producers. But in last year's there is a big problem that current energy consumption patterns in Algeria will no longer meet the increase in demand, accompanied by the decline in natural gas and crude oil production. Algeria need $<\mathrm{s}$ an energy transfer model that integrates other energy alternatives to meet future needs. Production with renewable energy in Algeria is the solution, because of its relatively large potential, which can reduce its dependence on this type of energy and the exploitation of renewable energies [1].

Long-term energy demand cannot be satisfied solely by fossil resources, in the process of exhaustion, an energy mix is essential. The renewable energies constitute an opportunity, particularly solar energy, for meet the needs of future generations. This energy mix strategy is motivated by several factors, such as: the availability of a large solar deposit, the density of a large electricity distribution network, lower prices for photovoltaic and wind turbines and the development of communications networks, such as the internet. Managing these new systems requires efficient means. The use of new Information and Internet Technologies, in the form of smart grids or "Smart Grid" provides a solution to the problems posed. Thus the systems used by the different electricity companies are in the private domain, their purchases where their rentals are very expensive. Free software presents an excellent alternative for developing mix-based systems management programs Energy. 


\section{Potential of Renewable Energies in Algeria}

Algeria relies almost exclusively on fossil fuels $(99.2 \%)$ to meet the growing electricity needs of its population. renewable energies thus occupy only a small part of the national electricity mix $(0.8 \%)$ and their production is shared between the hydraulic sector which generated this year $(389 \mathrm{GWh})$, or $0.7 \%$ of the total, and the solar photovoltaic $(11 \mathrm{Gwh})$ and thermodynamic (58GWh) sectors, which represent $0.1 \%$ of the balance sheet. Fossil production increased on average by $6.7 \%$ per year over the period 2002-2012. Algeria, however, is beginning a green dynamic today with the launch of a program providing for the installation of more than 2200 MW of 1200 MW renewable capacity dedicated to covering domestic electricity demand and $10000 \mathrm{MW}$ for export.

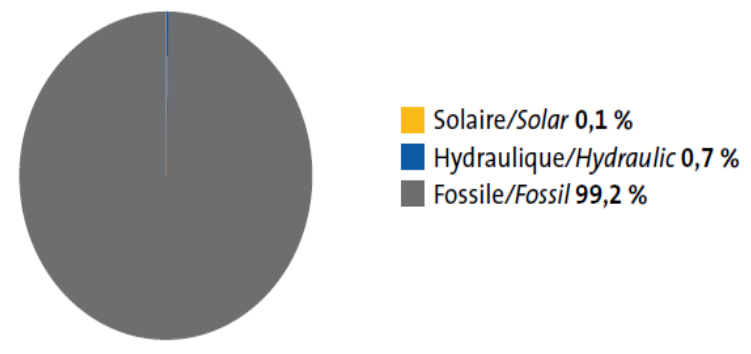

Fig. 1. Electrical production structure in 2016 [18]

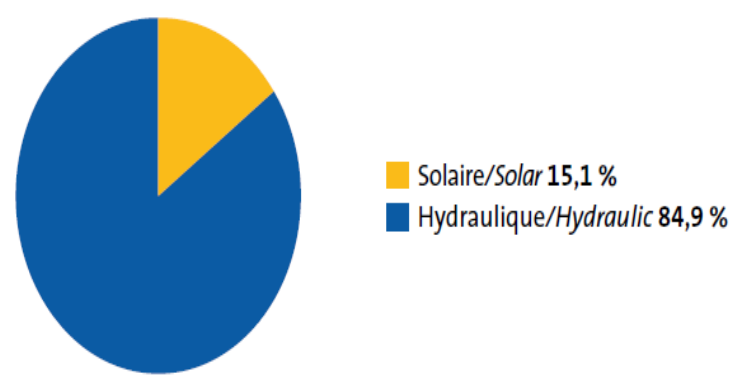

Fig. 2. Renewable electricity production in 2016 [18]

In addition, the option of nuclear power is still relevant to cope with the demand for rampant electricity and a first plant with a power of $1000 \mathrm{MW}$ could see the light in 2025. In parallel, some gas, which controls $75 \%$ of production capacity of the country, wishes to focus on the development of the new program for the green energy will rely largely on the solar sector for which Algeria has one of the best potential in the world. Algeria intends to position itself as a major player in the production of solar photovoltaic electricity, but also thermodynamics. The country inaugurated in July 2011 its first hybrid solar gas power plant with a power of $150 \mathrm{MW}$, including $30 \mathrm{MW}$ solar in the Saharan region Hassi R'mel [18].

\subsection{Solar Energy}

Algeria has one of the highest solar potentials in the world, estimated at 13.9 two per year [1]. Algeria has a great potential for solar energy. More than $2000000 \mathrm{~km}^{2}$ receive an annual exposure to the sun equivalent to 2500 Kwo $/ \mathrm{m}^{2}$ [2]. The sunstroke on almost the whole national territory exceeds the 2000 annual hours and can reach 3900 hours (high plains and Sahara). The daily energy obtained on a horizontal surface of $1 \mathrm{~m}^{2}$ is $5 \mathrm{Kwo}$ over most of the national territory, about $1700 \mathrm{Kwo} / \mathrm{m}^{2} /$ year for the North and $2263 \mathrm{Kwo} / \mathrm{m}^{2} /$ year for the South of the country [3] such as illustrated in (Table 1 and Figure $1)$.

Table 1. Solar potential in Algeria [3]

\begin{tabular}{|c|c|c|c|}
\hline Places & $\begin{array}{c}\text { Coastal } \\
\text { area }\end{array}$ & $\begin{array}{c}\text { High } \\
\text { plateau }\end{array}$ & Sahara \\
\hline Surface & 4 & 10 & 86 \\
\hline $\begin{array}{c}\text { Average duration of } \\
\text { sunning(Hours/ year) }\end{array}$ & 265 & 3000 & 3500 \\
\hline $\begin{array}{c}\text { Received average } \\
\text { energy(KWh/m²/year) }\end{array}$ & 1700 & 1900 & 2650 \\
\hline
\end{tabular}

Solar power has two main technologies: solar thermal and photovoltaic (PV gold). Solar thermal technology can provide heat and electrical energy Approximately 169, 440 Two.

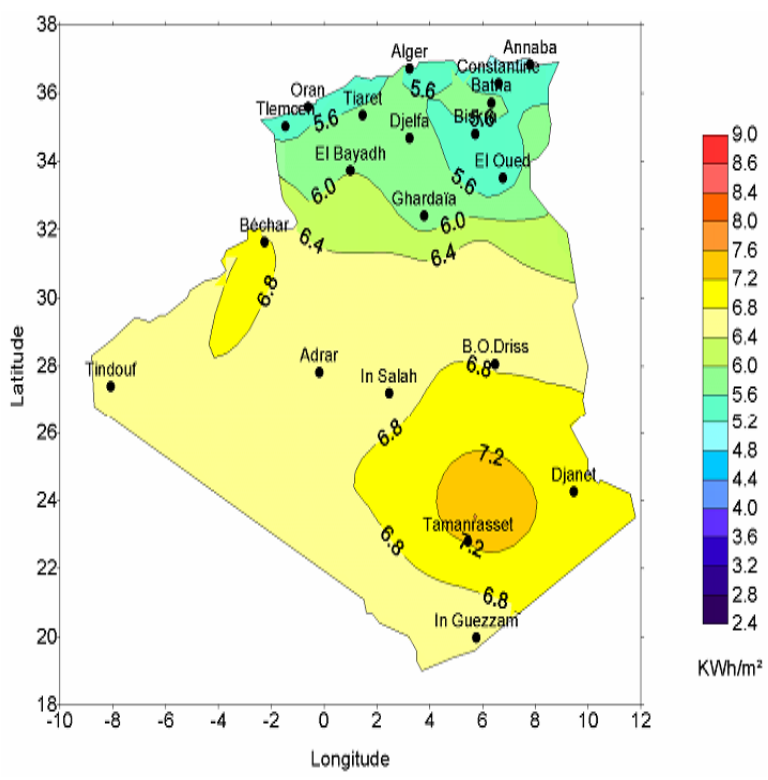

Fig. 3. Potential sites for solar electricity supply [3]. 
Per year, equivalent to 5,000 times the current energy consumption in the country, can be used to support various applications. The potential for solar energy in Algeria is 60 times the current electricity consumption of the EU.

Algerian houses can install solar thermal systems to heat water through sensors. For the production of electricity, it is preferable to use concentrated solar technology to operate steam and gas turbines that drive electric generators [1] as shown in Figure (4).
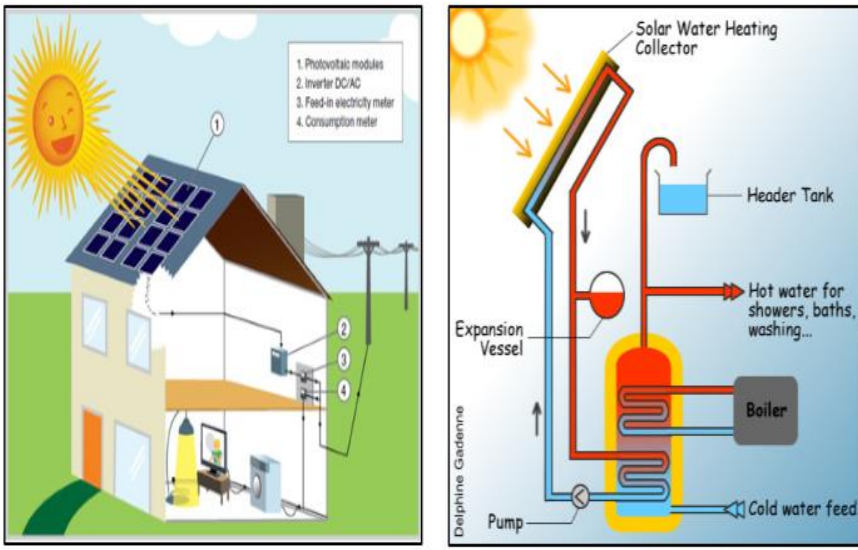

Fig. 4. Solar energy for production of electricity [6] and solar energy for heating system [5].

Solar power plants (with several solar stations) can be used in the south of country where solar radiation is concentrated on the top of a tower from concentrating mirrors. With photovoltaic panels, solar radiation is directly converted into electricity. This technology is widely used around the world and is considered a welldeveloped and mature technology.

The estimation of PV capacity is at $40 \mathrm{THhr} /$ year and can be used in various places, like fixing small panels on the roofs of homes, large panels in schools, hospitals and supermarkets and installation of big photovoltaic installations.

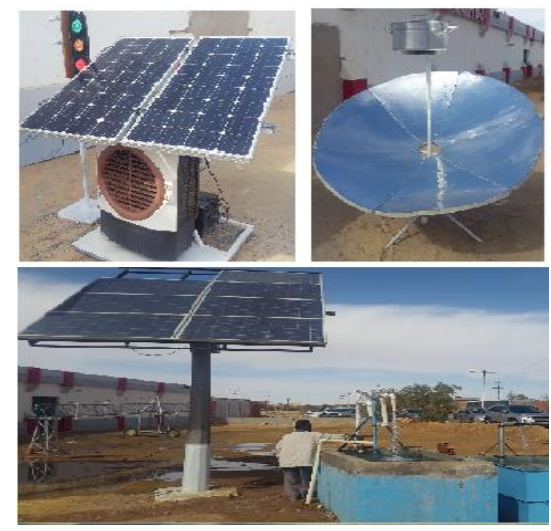

Fig. 5. Application of solar energy in Adrar.
General, different approaches technology for the utilization of solar energy will be assessed in the following section [4].

\subsection{Concentrating Solar Power}

Parabolic solar sector refers to technologies that allow electricity to be produced by concentrating solar radiation by means of mirrors or reflectors: this is called Concentrated Solar Power (CSP). As with concentrated solar photovoltaics, since diffuse radiation can not be focused, only direct sunlight (which represents between $50 \%$ and $90 \%$ of all solar radiation on the ground, depending on cloudiness) will be concentrated; but unlike solar photovoltaics in the case of solar thermodynamics, the concentration of the light ray will heat a heat transfer fluid that will be used, as in a conventional thermal power plant, to produce electricity. Therefore, solar thermodynamics requires high direct sunlight: sites must be in areas with direct radiation of about $1800 \mathrm{kWh} / \mathrm{m}^{2} /$ year. The markets concerned are similar to those of concentrated solar photovoltaics, namely the solar belt (mentioned above).

The expected technological advances are mainly in the development of optical systems and low-cost storage solutions as well as more efficient heat transfer fluids (to improve yields). The technology will also benefit from incremental technological improvements aimed at reducing maintenance costs (maintenance of the mirrors necessary to avoid losing performance points) and the costs of the various components (supports, tracking systems or trackers, mirrors, turbines, etc.).

Like all the technologies intended to recover an abundant but not very dense solar energy, the CSP solar farms have a large footprint on the ground. Thus, the Andasol power plant in Andalucia occupies an area of $510,000 \mathrm{~m} 2$ for a power of $50 \mathrm{MW}$ and a production of $180 \mathrm{GWh} /$ year[4].

Algeria's integrated combined cycle solar power plant is a hybrid power plant near Hassi R'Mel in Laghouat (25 MW parabolic solar power plant, with a $130 \mathrm{MW})$, reducing carbon emissions compared to a power plant traditional. The output of the solar network is used in the steam turbine [8].

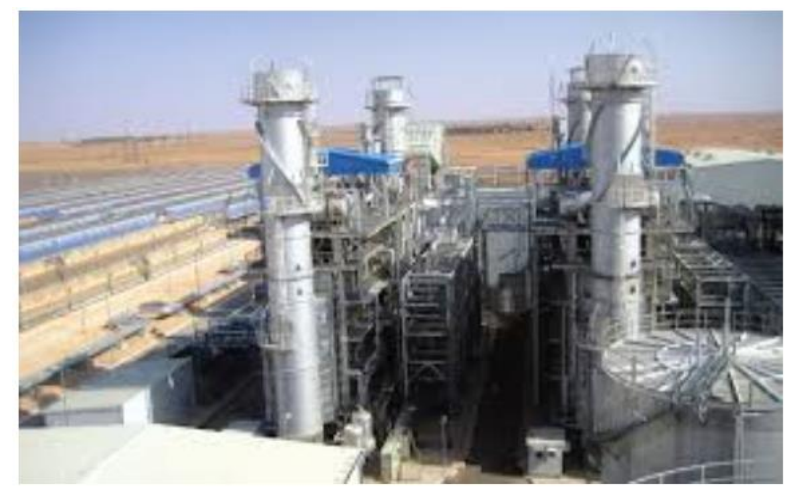

Fig. 6. Hybrid power plant near Hassi $\mathrm{R}^{\prime} \mathrm{Mel}$ in Laghouat 


\subsection{Photovoltaic Systems}

Photovoltaic solar is part of renewable energy. To harness this energy, we must design photovoltaic cells that convert light energy into electricity. This facility produces electricity that can be consumed locally by an individual or feed a distribution network (heat water or produce electricity). The networks can set up facilities like the Themis tower, it could reach $30 \%$ of solar energy converted into electricity thanks to gas and steam turbines. The energy is captured at the top of a tower at 1650 meters above sea level with mirrors and heliostats (adjustable mirrors) [18] like it show in the figure 4.

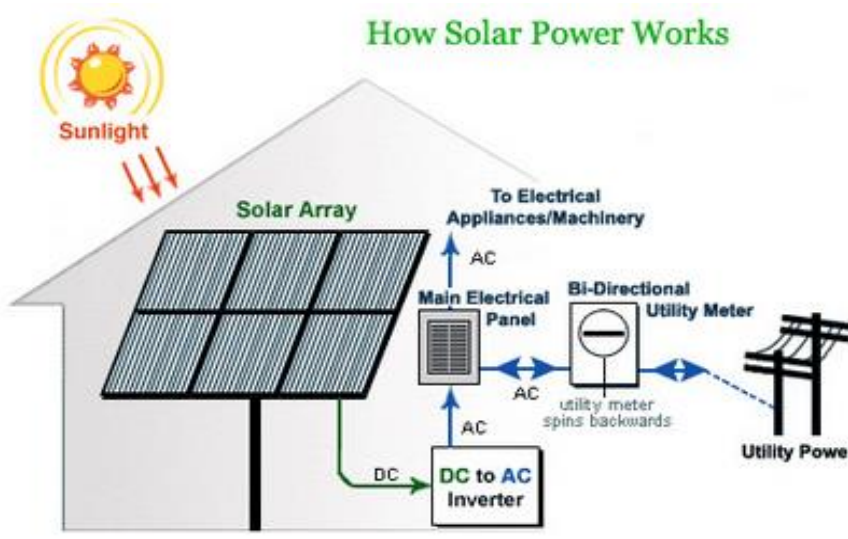

Fig. 7. Solar cell produce electricity [18].

In the coming years, the relatively limited needs of populations in southern Algeria, because of their low density, will be met. Future photovoltaic power plants will be located in the highlands region (Fig. 5). Like those currently in operation, these power stations serve to support the electricity grid in case of need, during the break of the day. The current form of exploitation of renewable energies in Algeria is highly centralized, the decentralized systems, which integrates the customer as consumer and producer are not topical.

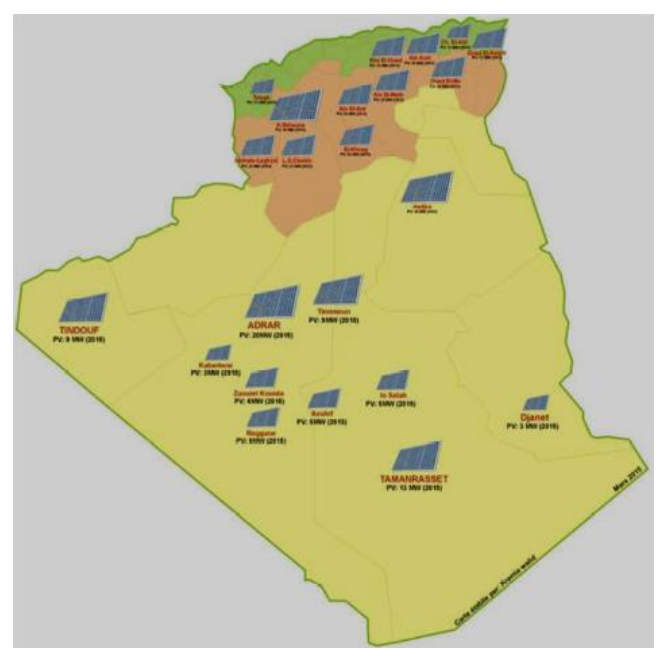

Fig. 8. The breakdown of photovoltaic plants by geographical region

\subsection{Wind Energy}

There are 21 zones offering adequate speed for the establishment of wind farms have been identified in anticipation of the establishment of future farms, which should take place in 2017, as shown in figure 6 .

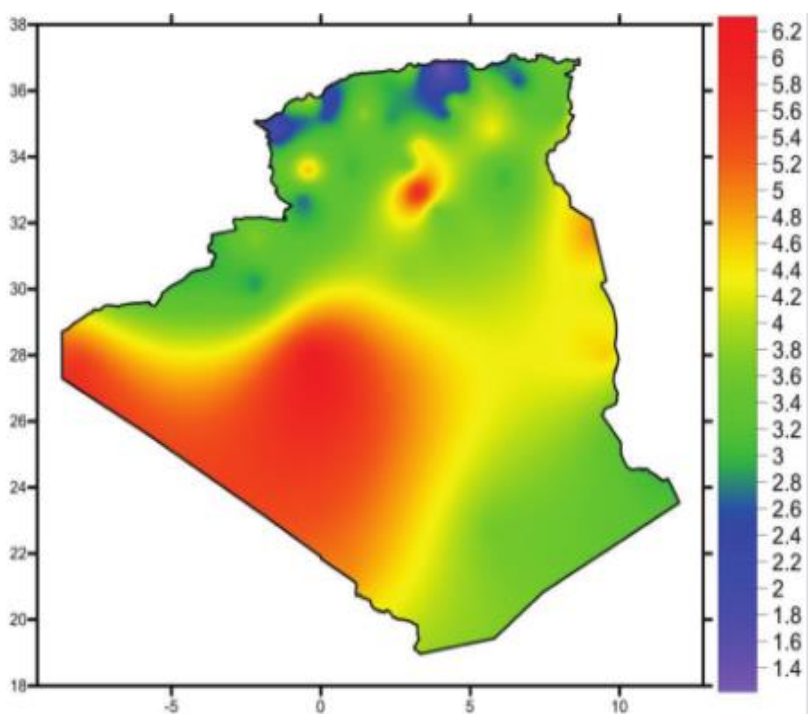

Fig. 9. Maps of the wind farm in Algeria (CDER 2013).

The region of Adrar, which is located in the south of Algeria, has a better potential for wind energy as shown in the figure below. The average annual wind speed is over $6 \mathrm{~m} / \mathrm{s}$ [16]. This makes it possible to supply electrical energy to isolated areas (FOGGARA, Kessour), where connection to the grid is not possible or very expensive [15].

The power generation plant with a capacity of 10 MW, which is located in the region of Kabertene, Willaya Adrar. This farm have 12 wind turbines with a capacity of $0.85 \mathrm{MW}$ each (fig. 10).

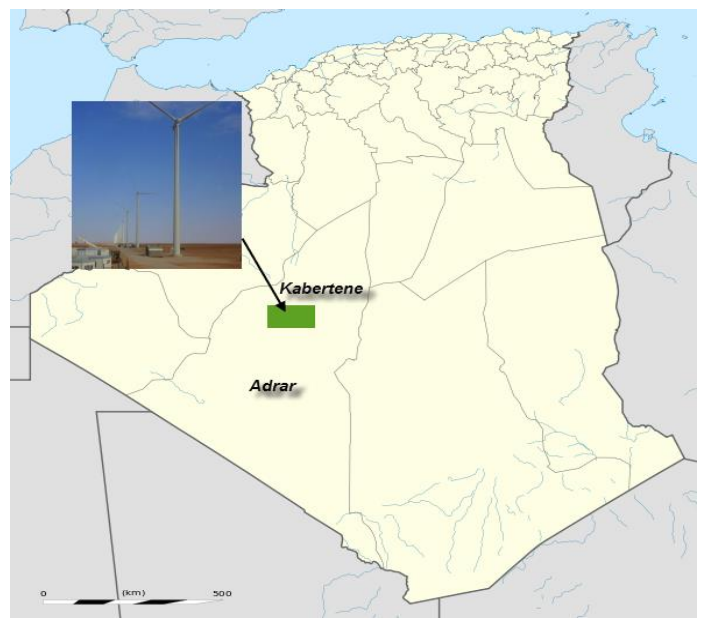

Fig.10. The power generation central "10 MW", Kabertene, Adrar. 


\section{Hybrid Electric Source Energy and Management}

To properly understand a management of energy sources, we gave an example that shows the management of energy systems for hybrid fuel cell power sources [17]. This model comes from MATLAB/Simulink we present the fuel cell based emergency power system.

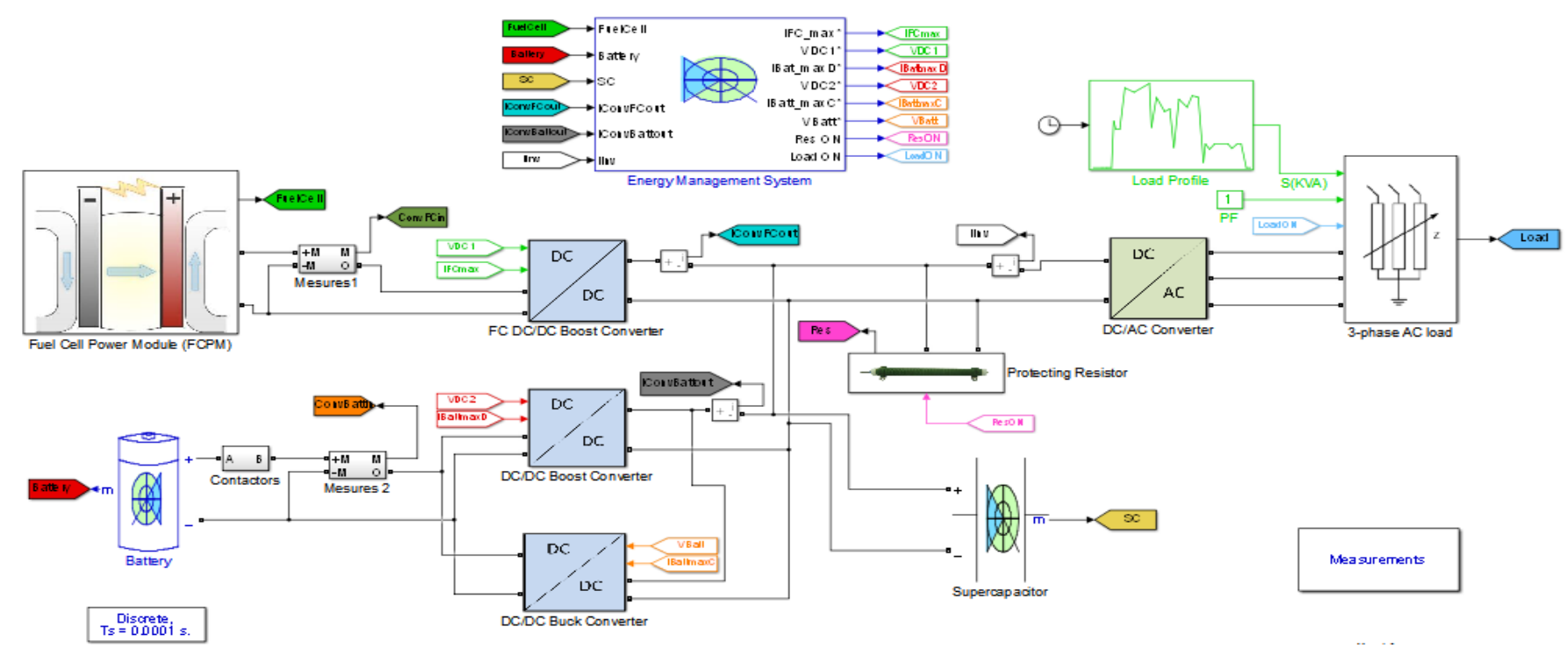

Fig. 11. Hybrid Electric Source Energy and Management Systems

Therefor, this structure features an alternative backup power system based on fuel cells, batteries and supercapacity. The demo also features various energy management systems for a hybrid fuel cell power source. This system is design for a representative emergency flight profile of a Bombardier aircraft and includes:

A $30-60 \mathrm{~V}$ (peak) PEM (proton exchange membrane) fuel cell module of $12.5 \mathrm{~kW}$ (peak), rated at 10 $\mathrm{kW}$.

A $48 \mathrm{~V}, 40 \mathrm{Ah}$ battery.

A super capacitor 291.6 V, 15.6 F.

A $12.5 \mathrm{~kW}$ DC / DC fuel cell converter with regulated output voltage and input current limitation.

Two DC / DC converters for discharging and charging the battery system.

Inverter with $15 \mathrm{kVA}, 270 \mathrm{~V} \mathrm{DC}, 200 \mathrm{~V} \mathrm{AC}, 400$ Hz.

Three-phase AC load with apparent power and variable power factor.

\section{A protection resistance of $15 \mathrm{~kW}$}

An energy management system that distributes power across energy sources based on a given energy management strategy.

Five types of energy management strategies are implemented, namely:

1. Control of the state machine;
2. The classic PI control;

3. Frequency decoupling and state machine control;

4. The strategy of minimizing the equivalent consumption;

5. The strategy of maximizing external energy.

Recent work shows that the performance of the hybrid fuel cell backup power system. It provides the essential loads in the next step:

Instantly when the main generators are lost.

Emergency hydraulic pump starts.

Movement of flaps / slats and landing gear.

Taxiing and evacuation of passengers

The energy management system controls the power of each energy source by the reference signals according to the type of control that is chosen from the energy management.

\section{Conclusion}

This article presents the renewable energies in Algeria, especially wind and solar sources, and other forms such as geothermal and biomass. These energies of the future offer very diverse and economical which can be installed in the present and future.

Although Algeria is set to be a game plan in renewable energy marketplace, the transition to renewable energies 
will have to be accelerate. However, this transition and highlight a smart policy especially if we consider the blurred picture of environmental and economic costs and the conflict they can create with renewable energy. In parallel with renewable energy development plans, the management of these sources must be carefully studied. At the end of this paper, we have gave example model of Energy Management Systems for a hybrid power source.

\section{References}

[1] Mokhtar Osmani , Faycel Loucif, "Renewable Energies and Shale Gas in Algeria, between fact and perspectives", Setif university.2016.

[2] Benahmed Khelifa , Smahi Abla , Hireche Samia, "Smart Grid in Algeria: Ambition Towards a Great Expectation (international Conference on Information Technology for Organization Development) 2014.

[3] Amine Boudghene Stambouli, "An overview of different energy sources in Algeria (page 4).

[4] Centre de recherche en économie appliquée pour le développement (CREAD) Algeria-A Future Supplier of Electricity from Renewable Energies For Europe? Algeria's Perspective and Current European Approaches.

[5] http://www.weatherenergy.co.uk/solar-thermal/how-itworks (last accessed on 25/03/2018)

[6] http://www.globalspec.com/learnmore/optics_optical_c omponents/optoelectronics/photovoltaic_cells (last accessed on 25/03/2018)

[7] http://www.sbcenergyinstitute.com/Publications/SolarP ower.html (last accessed on 25/03/2018)

[8] http://www.skyscrapercity.com/showthread.php?t=128 3009 (last accessed on 25/03/2018)

[9] https://en.wikipedia.org/wiki/Hassi_R'Mel_integrated_ solar_combined_cycle_power_station

[10] www.cder.dz (last accessed on 25/03/2018)

[11] www.sonelgz.dz (last accessed on 25/03/2018)

[12] Lokman Hadji, "How is 100\% Renewable Energy Possible for Algeria by 2030?”, May, 2016.

[13] A. Harrouz, A. Benatialah and O. Harrouz," Direct Power Control of a PMSG Dedicated to Standalone Wind Energy Systems», Journal "IEEE Xplore, "Eighth International Conference and Exhibition on Ecological Vehicles and Renewable Energy", March 27-30, 2013, Monaco, France, 2013.

[14]E. Mahersi, Adel Khedher, F. Mimouni, "The Wind energy Conversion System Using PMSG Controlled by Vector Control and SMC Strategies", International journal of renewable energy research emna mahersi et al., vol.3, no.1, 2013.

[15] A. Harrouz, A. Benatiallah, O. Harrouz, "Modeling of small wind energy based of PMSG in south of
Algeria", Journal "IEEE Explore" of 2nd International Symposium on Environment-Friendly Energies and Applications(EFEA2012);10.1109/EFEA.2012.629404 2, pp. 191 - 195, 2012, University Northumbrie, UK.

[16]N. Kasbadji Merzouk ; ' Quel avenir pour l'Énergie Éolienne en Algérie ?’. Bul. Ene. Ren, CDER, N 14 , p.6-7, 2008.

[17] Souleman Njoya M., Louis-A. Dessaint and Susan Liscouet-Hanke, "Energy Management Systems for a Hybrid Electric Source", 2015.

[18] http://mistersustainable.blogspot.com/2015/04/solarcollectors-and-panels-explained.html (last accessed on 25/03/2018)

[19] Adel Ghouari, «Étude théorique et expérimentale des réseaux intelligents appliqués dans la gestion d'énergie des systèmes photovoltaïques connectés au réseau électrique », thèse doctorat Informatique Industrielle et Productique, university of Batna , 2017. 